\title{
Incorporation and profile of fatty acids in tilapia fillets (Oreochromis niloticus) fed with tung oil
}

\author{
Incorporação e perfil de ácidos graxos em filés de tilápia \\ (Oreochromis niloticus) alimentada com óleo de tungue
}

\begin{abstract}
Elton Guntendorfer BONAFÉ ${ }^{1 *}$, Damila Rodrigues de MORAIS $^{1}$, Luana Caroline de FIGUEIREDO ${ }^{1}$, Nilson Evelázio SOUZA ${ }^{1}$, Oscar Oliveira SANTOS ${ }^{1}$, Thiago CLAUS ${ }^{1}$, Jesuí Vergílio VISENTAINER ${ }^{1}$
\end{abstract}

\begin{abstract}
The acceptance of tung oil enriched diet and the incorporation of conjugated linolenic acid - CLnA into fillets of Genetically Improved Farmed Tilapia (GIFT) were investigated. The diet was well accepted, and after 10 days CLnA was incorporated into the fillets with a 1.02\% content of total fatty acids (FA). In addition, biosynthesis of the conjugated linoleic acid isomers - CLA ( $0.31 \%$ of fillet total FA content) from CLnA, and the presence of alpha-linolenic acid - LNA (1.08\% of fillet total FA content), eicosapentaenoic acid - EPA (2.85\% of fillet total FA content) and docosahexaenoic acid - DHA (3.08\% of fillet total FA content) were observed. Therefore, the consumption of this fish can increase the intake of different FA (CLnA, CLA, LNA, EPA and DHA), which play an important role in human metabolism.

Keywords: conjugated linolenic acid; tilapia fillet; genetically improved farmed tilapia.
\end{abstract}

\section{Resumo}

A aceitação de tratamentos enriquecidos com óleo de tungue e a incorporação do ácido linolênico conjugado (CLnA) em filés de tilápia melhorada geneticamente (GIFT) foram investigadas. A dieta teve boa aceitação e, após 10 dias, o ClnA havia sido incorporado nos filés, mostrando um teor de 1,02\% dos ácidos graxos totais (AG). Além disso, a biossíntese dos isômeros do ácido linoleico conjugado - CLA ( $0,31 \%$ de teor de AG total no filé), a partir do CLnA, e a presença do ácido alfalinolênico - LNA (1,08\% de teor de AG total no filé), ácido eicosapentaenoico - EPA (2,85 \% de teor de AG total no filé) e ácido docosa-hexaenoico - DHA (3,08\% de teor de AG total no filé) foram observados. Assim, o consumo deste peixe pode aumentar a ingestão de diferentes AG (CLnA, CLA, LNA, EPA e DHA), que desempenham um papel importante no metabolismo humano.

Palavras-chave: ácido linoleico conjugado; filé de tilápia; filés de tilápia melhorada geneticamente.

\section{Introduction}

Tilapia (Oreochromis niloticus) originally comes from the Nile basin (NOVA; GODOY; ALDRIGUE, 2005) and is the second most important fish in aquaculture in the world. Due to its reproductive biology, ruggedness, genetic plasticity, fast growth, feed intake and favorable commercialization, Genetically Improved Farmed Tilapia (GIFT) was developed and introduced in Brazil in 2005 (FÜLBER et al., 2009).

Easiness in breeding tilapia, together with the fact that its fillet fatty acid (FA) profile is influenced by its diet (VISENTAINER et al., 2005), raises great interest in evaluating the incorporation of fatty acids beneficial to health into its muscle tissues.

Although the interest of researchers in evaluating the incorporation of different fatty acids into tilapia muscle tissues has resulted in some scientific studies (VISENTAINER et al., 2005; SOUZA et al., 2007; JUSTI et al., 2003; OMENA et al., 2010), the dietary supplementation of these fish with the geometric and positional isomers of octadecatrienoic acid (18:3n-3), also known as conjugated linolenic acid (CLnA) (YANG et al., 2009), has never been evaluated. Some of its isomers have proven biological activity (SEÇKIN et al., 2005; SUZUKI et al., 2001; YASUI et al., 2005).

CLnA are found in seed oils, especially in tung oil, as major FA: $\alpha$-eleostearic acid (alpha-ESA, 9c,11t,13t) and $\beta$-eleostearic acid (beta-ESA, 9t,11t,13t) (CAO et al., 2006). Some CLnA isomers show cytotoxic effects on tumors, inhibit carcinogenesis, and alter lipid metabolism (DESTAILLATS et al., 2005; SUZUKI et al., 2001; YASUI et al., 2005).

One of the most commonly used techniques for FA separation and detection in a number of food matrices is gas chromatography coupled to a flame ionization detector, GC-FID (SIMAS et al., 2010). Therefore, the objective of this study was to evaluate the fatty acid composition of Genetically Improved Farmed Tilapia (GIFT) enriched with conjugated fatty acids, found in tung oil, using GC-FID.

\section{Materials and methods}

Standards. FAMEs 189-19 mixture standard and methyl tricosanoate were purchased from Sigma-aldrich (USA). The

${ }^{1}$ Departamento de Química, Universidade Estadual de Maringá - UEM, Av. Colombo, 5790, CEP 87020-900, Maringá, PR, Brazil, e-mail: g_bonafe@yahoo.com.br 
other reagents such as chloroform, methanol, ammonia, as well as sodium hydroxide, heptane, sulfuric acid, and sodium chloride were also purchased from Sigma-aldrich.

Sampling. Fish was raised at the Fish Experimental Station of State University of Maringá, UEM/Codapar, located in the District of Floriano (Maringá, Paraná state, Brazil) in February 2010. 400 fish weighing an average of $40.56 \pm 0.67 \mathrm{~g}$ were distributed into eight tanks and submitted to two treatments with four replicates. The ingredients used in the preparation of the two treatments, a control containing sunflower oil and the experimental feed enriched with tung oil, are shown in Table 1. The feeds were prepared according to the nutritional needs of tilapia (WASHINGTON, 1993). Two week before starting the experiment, the fish received the control treatment oil (with sunflower oil and without tung oil) for adaptation. After this period, the tanks were equally divided for the two treatments, and the fish were fed twice daily. The fish were evaluated for ten days; on days 0 and 10, a total of six tilapias were killed for each repetition, eviscerated, washed, filleted, ground, and freeze stored in $\mathrm{N}_{2}$ atmosphere in polyethylene bags at $-18{ }^{\circ} \mathrm{C}$ for subsequent analysis.

Analyses. The moisture content in the fillets and feeds was determined as described by Cunniff (1998), and the total lipids (TL) were determined by the Bligh and Dyer (1959) method.

Table 1. Composition of experimental feeds ${ }^{\mathrm{A}}$.

\begin{tabular}{|c|c|c|}
\hline \multirow[t]{2}{*}{ Ingredients (\%) } & \multicolumn{2}{|c|}{$\begin{array}{l}\text { Treatments } \\
\text { V (LNA) } 5 \\
\end{array}$} \\
\hline & Sunflower oil & Tung oil \\
\hline Soybean bran & 53.65 & 53.65 \\
\hline Maize & 21.18 & 21.18 \\
\hline Wheat bran & 8.62 & 8.62 \\
\hline Brewers rice & 7.66 & 7.66 \\
\hline Bicalcium phosphate & 2.87 & 2.87 \\
\hline Salt & 0.48 & 0.48 \\
\hline Choline chloride & 0.10 & 0.10 \\
\hline Antifungal & 0.10 & 0.10 \\
\hline Vitamin C (mono) & 0.10 & 0.10 \\
\hline Antioxidant & 0.04 & 0.04 \\
\hline DL-Methionine & 0.14 & 0.14 \\
\hline L-Lysine & 0.19 & 0.19 \\
\hline L-Threonine & 0.14 & 0.14 \\
\hline L-Tryptophan & 0.05 & 0.05 \\
\hline Premix $^{\mathrm{B}}$ & 0.48 & 0.48 \\
\hline Sunflower oil & 4.2 & 0 \\
\hline Tung oil & 0 & 4.2 \\
\hline \multicolumn{3}{|l|}{ Composition $^{\mathrm{C}}(\%)$} \\
\hline Ash & $7.40 \pm 0.00$ & $7.50 \pm 0.07$ \\
\hline Crude protein & $33.86 \pm 0.71$ & $33.81 \pm 0.10$ \\
\hline Moisture & $3.83 \pm 0.01$ & $3.82 \pm 0.04$ \\
\hline Total lipids & $6.48 \pm 0.22$ & $6.54 \pm 0.10$ \\
\hline
\end{tabular}

Preparation of Fatty Acid Methyl Esters (FAME). Fatty acid methyl esters were obtained from $30 \pm 1 \mathrm{mg}$ of oil extracted from fillets to which $500 \mu \mathrm{L}$ of a methyl tricosanoate solution in n-heptane at $1 \mathrm{mg} \cdot \mathrm{mL}^{-1}$ in a screw-cap test tube were added. After solvent evaporation under nitrogen flow, the lipids were saponified in a $0.5 \mathrm{~mol} . \mathrm{L}^{-1}$ sodium hydroxide solution in methanol and esterified using a mixture of ammonium chloride, methanol, and sulfuric acid in the proportion of 1:30:1.5 (m/v/v). After the addition of $4 \mathrm{~mL}$ of a saturated sodium chloride solution, the esters were extracted with $1 \mathrm{~mL}$ of n-heptane (JOSEPH; ACKMAN, 1992) and freeze stored $\left(-18^{\circ} \mathrm{C}\right)$ for subsequent chromatographic analysis.

GC Analyses of Methyl Ester. Methyl ester was separated by gas chromatography using a Thermo 3300 gas chromatograph fitted with a flame ionization detector (FID) and a fused-silica CP-7420 (SELECT FAME) capillary column $(100 \mathrm{~m} \times 0.25 \mathrm{~mm}$ i.d. $\times 0.25 \mu \mathrm{m}$ of cianopropil). The operating parameters were as follows: detector temperature, $240{ }^{\circ} \mathrm{C}$; injection port temperature, $230{ }^{\circ} \mathrm{C}$; column temperature, $165^{\circ} \mathrm{C}$ for 18 minutes, programmed to increase at $4{ }^{\circ} \mathrm{C} \cdot \mathrm{min}^{-1}$ up to $235^{\circ} \mathrm{C}$ with a final holding time of 14.5 minutes; carrier gas hydrogen at $1.2 \mathrm{~mL} \cdot \mathrm{min}^{-1}$; nitrogen makeup gas at $30 \mathrm{~mL} \cdot \mathrm{min}^{-1}$; and split injection at 1:80 ratio. For identification, the retention times of the fatty acids were compared to those of standard methyl esters (Sigma, St. Louis, MO). Retention times and peak area percentages were automatically processed using the Software Chromquest 5.0.

Statistics. The mean values were statistically compared by the Tukey test at $5 \%$ using one-way ANOVA. The data were processed using software Statistica 6.0.

\section{Results and discussion}

Control and experimental treatment fish received isocaloric and isoproteic feeds (Table 1) in order to meet their basic nutritional needs and allow their growth to calculate the correlation of the differences between their fillets and those obtained from the oil- enriched treatment.

Control in preparing the diets and their acceptance by the fish are basic factors in this kind of study. Both experimental diets (with sunflower seed oil and tung oil) were well accepted by the fish; no mortality was recorded.

With regards to fatty acids, the control diet (sunflower oilenriched) did not contain conjugated alpha-ESA and beta-ESA fatty acids, which is the main objective of this study, while these are present among the major FA in the experimental treatment (tung oil-enriched) (Table 2).

Table 3 shows the amounts of 42 fatty acids found in the muscle tissue of tilapias submitted to the different treatments. The fatty acids identified were saturated fatty acids (SFA), monounsaturated (MUFA), and polyunsaturated fatty acids (PUFA) (SOUZA et al., 2007). Palmitic acid (16:0) was the saturated fatty acid (SFA) found in the greatest amount, followed by MUFA and PUFA oleic acid (18:1n-9) and linoleic acid (18:2n-6), respectively. The same was observed in Nile tilapia fed modified diets (JUSTI et al., 2003). 
Table 2. Fatty acid profiles (g $100 \mathrm{~g}^{-1}$ total lipids) of sunflower and tung oil.

\begin{tabular}{|c|c|c|}
\hline Fatty acids & Sunflower oil & Tung oil \\
\hline $16: 0$ & $9.73 \pm 0.18^{\mathrm{a}}$ & $8.77 \pm 0.09^{\mathrm{b}}$ \\
\hline $16: 1 n-7$ & $0.11 \pm 0.00^{\mathrm{a}}$ & nd \\
\hline 18:0 & $2.00 \pm 0.02^{\mathrm{a}}$ & $2.51 \pm 0.27^{\mathrm{b}}$ \\
\hline $18: 1 n-9$ & $22.89 \pm 0.04^{\mathrm{a}}$ & $11.20 \pm 0.39^{\mathrm{b}}$ \\
\hline $18: 1 n-7$ & $0.90 \pm 0.07^{\mathrm{a}}$ & $0.76 \pm 0.03^{\mathrm{b}}$ \\
\hline $18: 2 n-6$ & $59.71 \pm 0.10^{\mathrm{a}}$ & $25.93 \pm 1.05^{\mathrm{b}}$ \\
\hline $18: 29 \mathrm{c} 11 \mathrm{t}$ & nd & nd \\
\hline $18: 210 \mathrm{t} 12 \mathrm{c}$ & nd & nd \\
\hline $18: 3 n-3$ & $3.04 \pm 0.02^{\mathrm{a}}$ & $2.23 \pm 0.01^{\mathrm{b}}$ \\
\hline alpha-ESA $(9 c, 11 t, 13 t)$ & nd & $28.73 \pm 0.35$ \\
\hline $\mathrm{X} 1$ & nd & $1.06 \pm 0.03$ \\
\hline $\mathrm{X} 2$ & nd & $2.87 \pm 0.08$ \\
\hline $\mathrm{X} 3$ & nd & $2.45 \pm 0.03$ \\
\hline beta-ESA $(9 t, 11 t, 13 t)$ & nd & $12.64 \pm 0.08$ \\
\hline $20: 0$ & $0.44 \pm 0.02^{\mathrm{a}}$ & $0.19 \pm 0.01^{\mathrm{b}}$ \\
\hline $20: 1 n-9$ & $0.21 \pm 0.01^{\mathrm{a}}$ & nd \\
\hline 22:0 & $0.32 \pm 0.00^{\mathrm{a}}$ & nd \\
\hline $22: 1 n-7$ & $0.47 \pm 0.00^{\mathrm{a}}$ & $0.67 \pm 0.03^{\mathrm{b}}$ \\
\hline $24: 0$ & $0.19 \pm 0.00^{\mathrm{a}}$ & nd \\
\hline \multicolumn{3}{|c|}{ Fatty Acid Sums and Ratios } \\
\hline PUFA & $62.75^{\mathrm{a}}$ & $75.90^{\mathrm{b}}$ \\
\hline SFA & $12.68^{\mathrm{a}}$ & $11.47^{\mathrm{b}}$ \\
\hline CLnA & nd & $47.75^{\mathrm{b}}$ \\
\hline CLA & nd & nd \\
\hline$n-6$ & $59.71^{\mathrm{a}}$ & $25.93^{b}$ \\
\hline$n-3$ & $3.04^{\mathrm{a}}$ & $2.23^{\mathrm{b}}$ \\
\hline PUFA/SFA & $4.95^{\mathrm{a}}$ & $6.62^{\mathrm{b}}$ \\
\hline$n-6 / n-3$ & $19.64^{\mathrm{a}}$ & $11.63^{\mathrm{b}}$ \\
\hline
\end{tabular}

Results expressed as relative percentage of average total fatty acid of three replicates. Different letters in the same line indicate significant difference $(\mathrm{P}<0.05)$ by the Tukey test. SFA $=$ saturated fatty acids; MUFA = monounsaturated fatty acids; PUFA $=$ polyunsaturated fatty acids; $C L n A=$ linolenic fatty acids; CLA = linoleic fatty acids; $\mathrm{n}-6=$ total of $\mathrm{n}-6$ fatty acids. $\mathrm{n}-3=$ total of $\mathrm{n}-3$ fatty acids; $\mathrm{X} 2, \mathrm{X} 3$, and $\mathrm{X} 4=$ isomers of linolenic acids not identified.

Palmitic (16:0), oleic (18:1n-9), linoleic (18:2n-6), and linolenic (18:3n-3) FA were also major FA in the two feeds and in the fillets (Table 3). According to Bellido et al. (2006), the ingestion of oleic acid is related to the reduction of the level of low density proteins (LDL) and consequently, the prevention of arteriosclerosis. The results to this fatty acid ranged from 20.48 to $21.78 \%$ for sunflower and tung treatments, as shown in Table 3. LA and LNA, were also found in both treatments with levels between 20.19 and $0.88 \%$ and 21.11 and $1.08 \%$ for sunflower and tung treatments, respectively. These fatty acids are essential fatty acids metabolized by the same sequential denaturation and elongation enzyme systems, which results in the production of long-chain polyunsaturated fatty acids (LC-PUFA) of the n-3 and n- 6 series (SOUZA et al., 2007). Usually, the FA profile of tilapia fillets contains FA which play an important role in human metabolism (MARTIN et al., 2006) such as alpha-linoleic acid (LNA), eicosapentaenoic acid (EPA), and docosahexaenoic acid (DHA), which belong to the n-3 series and contribute to the increase of the nutritional value of this meat.
Table 3. Fatty acid profile (g $100 \mathrm{~g}^{-1}$ total lipids) ${ }^{\mathrm{a}}$ of fillets of tilapia submitted to feeds enriched with sunflower or tung oil.

\begin{tabular}{|c|c|c|}
\hline \multirow{2}{*}{ Fatty acids ${ }^{\mathrm{b}}$} & \multicolumn{2}{|c|}{ Oils } \\
\hline & Sunflower $(0 \text { days })^{c}$ & Tung $(10 \text { days })^{\mathrm{d}}$ \\
\hline 14:0 & $1.20 \pm 0.01^{\mathrm{a}}$ & $1.31 \pm 0.01^{\mathrm{b}}$ \\
\hline i15:0 $0^{\mathrm{e}}$ & $0.14 \pm 0.00^{\mathrm{a}}$ & $0.18 \pm 0.00^{\mathrm{b}}$ \\
\hline $15: 0$ & $0.31 \pm 0.00^{\mathrm{a}}$ & $0.31 \pm 0.00^{\mathrm{b}}$ \\
\hline $\mathrm{i} 16: 0^{\mathrm{e}}$ & $0.74 \pm 0.00^{\mathrm{ac}}$ & $0.50 \pm 0.01^{\mathrm{b}}$ \\
\hline $16: 0$ & $18.98 \pm 0.07^{a}$ & $18.03 \pm 0.03^{b}$ \\
\hline $16: 1 n-9$ & $0.60 \pm 0.01^{\mathrm{a}}$ & $0.59 \pm 0.01^{\mathrm{a}}$ \\
\hline $16: 1 n-7$ & $1.97 \pm 0.01^{\mathrm{a}}$ & $2.37 \pm 0.01^{\mathrm{b}}$ \\
\hline $16: 1 n-5$ & $0.30 \pm 0.00^{\mathrm{a}}$ & $0.35 \pm 0.00^{\mathrm{b}}$ \\
\hline ail7:0 $0^{\mathrm{e}}$ & $0.10 \pm 0.00^{\mathrm{a}}$ & $0.12 \pm 0.00^{\mathrm{a}}$ \\
\hline $17: 0$ & $0.47 \pm 0.00^{\mathrm{a}}$ & $0.49 \pm 0.00^{\mathrm{b}}$ \\
\hline $17: 1 n-9$ & $0.40 \pm 0.01^{\mathrm{a}}$ & $0.26 \pm 0.00^{\mathrm{b}}$ \\
\hline $18: 0$ & $7.47 \pm 0.01^{\mathrm{a}}$ & $6.92 \pm 0.02^{\mathrm{b}}$ \\
\hline $18: 1 n-11$ & $0.27 \pm 0.01^{\mathrm{a}}$ & $0.23 \pm 0.01^{\mathrm{a}}$ \\
\hline $18: 1 n-9$ & $20.48 \pm 0.06^{\mathrm{a}}$ & $21.78 \pm 0.03^{b}$ \\
\hline $18: 1 n-7$ & $2.54 \pm 0.01^{\mathrm{a}}$ & $2.55 \pm 0.00^{\mathrm{a}}$ \\
\hline $18: \ln -4$ & $0.21 \pm 0.00^{\mathrm{a}}$ & $0.17 \pm 0.00^{\mathrm{b}}$ \\
\hline $18: 2 n-6(L A)$ & $20.19 \pm 0.07^{\mathrm{a}}$ & $21.11 \pm 0.10^{\mathrm{a}}$ \\
\hline $18: 2 n-4$ & $0.15 \pm 0.00^{\mathrm{a}}$ & $0.16 \pm 0.01^{\mathrm{b}}$ \\
\hline $18: 3 n-6$ & $0.92 \pm 0.00^{\mathrm{a}}$ & $0.90 \pm 0.01^{\mathrm{b}}$ \\
\hline 18:3n-3 (LNA) & $0.88 \pm 0.00^{\mathrm{a}}$ & $1.08 \pm 0.01^{\mathrm{b}}$ \\
\hline $18: 2 \mathrm{c} 9 \mathrm{t} 11$ & nd & $0.14 \pm 0.00^{\mathrm{a}}$ \\
\hline $19: 2 n-7$ & $0.21 \pm 0.00^{\mathrm{a}}$ & $0.25 \pm 0.01^{\mathrm{b}}$ \\
\hline $18: 2 \mathrm{t} 10 \mathrm{c} 12$ & nd & $0.17 \pm 0.00^{\mathrm{a}}$ \\
\hline $18: 4 n-3$ & $0.10 \pm 0.00^{\mathrm{a}}$ & $0.08 \pm 0.01^{\mathrm{a}}$ \\
\hline $20: 1 n-9$ & $1.00 \pm 0.00^{\mathrm{a}}$ & $1.28 \pm 0.01^{\mathrm{b}}$ \\
\hline $21: 0$ & $0.08 \pm 0.00^{\mathrm{a}}$ & $0.09 \pm 0.00^{\mathrm{a}}$ \\
\hline $20: 2 n-6$ & $1.37 \pm 0.01^{\mathrm{a}}$ & $1.34 \pm 0.00^{\mathrm{a}}$ \\
\hline $20: 3 n-6$ & $1.47 \pm 0.01^{\mathrm{a}}$ & $1.48 \pm 0.01^{\mathrm{b}}$ \\
\hline $20: 4 n-6(A A)$ & $3.60 \pm 0.01^{\mathrm{a}}$ & $3.05 \pm 0.01^{b}$ \\
\hline $20: 4 n-3$ & $0.23 \pm 0.00^{\mathrm{a}}$ & $0.27 \pm 0.00^{\mathrm{b}}$ \\
\hline 22:0 & $0.16 \pm 0.00^{\mathrm{ab}}$ & $0.16 \pm 0.01^{\mathrm{a}}$ \\
\hline alpha-ESA & nd & $0.41 \pm 0.00^{\mathrm{a}}$ \\
\hline $\mathrm{X} 2$ & nd & $0.08 \pm 0.00^{\mathrm{a}}$ \\
\hline $\mathrm{X} 3$ & nd & $0.12 \pm 0.01^{\mathrm{a}}$ \\
\hline $\mathrm{X} 4$ & nd & $0.22 \pm 0.01^{\mathrm{a}}$ \\
\hline beta-ESA & nd & $0.19 \pm 0.00^{\mathrm{a}}$ \\
\hline 20:5n-3 (EPA) & $3.22 \pm 0.01^{\mathrm{a}}$ & $2.85 \pm 0.06^{\mathrm{b}}$ \\
\hline $22: 4 n-6$ & $1.37 \pm 0.01^{\mathrm{a}}$ & $1.21 \pm 0.01^{\mathrm{b}}$ \\
\hline $22: 5 n-6$ & $4.04 \pm 0.01^{\mathrm{a}}$ & $2.96 \pm 0.01^{b}$ \\
\hline $24: 0$ & $0.17 \pm 0.00^{\mathrm{a}}$ & $0.20 \pm 0.01^{\mathrm{b}}$ \\
\hline 24:1n-9 & $0.87 \pm 0.00^{\mathrm{a}}$ & $0.96 \pm 0.00^{\mathrm{b}}$ \\
\hline 22:6n-3 (DHA) & $3.79 \pm 0.02^{\mathrm{a}}$ & $3.08 \pm 0.02^{\mathrm{b}}$ \\
\hline
\end{tabular}

aResults expressed as relative percentage of average total fatty acids of three replicates. Different letters in the same line indicate significant difference $(\mathrm{P}<0.05)$ by the Tukey test. ${ }^{b}$ Results expressed as averages of six replicates. Different letters in the same line indicate significant difference $(\mathrm{P}<0.05)$ by the Tukey test. ${ }^{c} 0$ days $=$ adaptation time (sunflower oil). ${ }^{\mathrm{d}} 0$ days $=$ Duration of the tung oil treatment. ${ }^{e} \mathrm{i}$ and $\mathrm{ai}=$ iso and anteiso fatty acids isomers; $\mathrm{LA}=$ linoleic acid; $\mathrm{LNA}=$ alpha-linolenic acid; $\mathrm{AA}=$ arachidic acid; EPA = eicosapentaenoic acid; DHA = docosahexaenoic acid; alpha-ESA = alphaeleostearic acid, 18:3 c9, t11, t13; beta-ESA = beta-eleostearic acid 18:3 t9, t11, t13; CLA = conjugated linoleic acid (18:2 9c11t, 18:2 10t12c); nd = not detected; X2, X3, and $\mathrm{X} 4=$ isomers of linolenic acids not identified. 
Table 4. Moisture, total lipids, and Fatty Acid Sums and Ratio ${ }^{a}$ of fillets of tilapia submitted to feeds enriched with sunflower or tung oil.

\begin{tabular}{lcc}
\hline \multicolumn{1}{c}{ Analyses (\%) } & Sunflower oil & Tung oil \\
\hline Moisture & $80.36 \pm 0.19^{\mathrm{a}}$ & $80.07 \pm 0.13^{\mathrm{a}}$ \\
Total lipids & $0.57 \pm 0.00^{\mathrm{a}}$ & $0.70 \pm 0.00^{\mathrm{b}}$ \\
& Fatty Acid Sums and Ratio \\
PUFA & 42.12 & 40.07 \\
SFA & 30.22 & 28.48 \\
CLA & 0.00 & 0.31 \\
CLnA & 0.00 & 1.02 \\
$\mathrm{n}-6$ & 33.41 & 32.25 \\
$\mathrm{n}-3$ & 8.34 & 7.42 \\
PUFA/SFA & 1.39 & 1.41 \\
$\mathrm{n}-6 / \mathrm{n}-3$ & 4.01 & 4.35 \\
\hline aResults expressed as relative percentage of average total fatty acids of three \\
replicates; SFA = saturated fatty acids; MUFA = monounsaturated fatty acids; \\
PUFA = polyunsaturated fatty acids; CLnA = linolenic fatty acids; CLA = linoleic fatty \\
acids; $\mathrm{n}-6=$ total of $\mathrm{n}$-6 fatty acids and n-3 = total of n-3 fatty acids.
\end{tabular}

Table 4 shows the FA ratios n-6/n-3 and PUFA/SFA. It also shows important information concerning the food because according to Simopoulos (2002), for food to be considered healthy, these ratios must be smaller than 4.0 and greater than 0.4 , respectively. In the present study, the $n-6 / n-3$ and PUFA/ SFA ratios in the tilapia fillets were satisfactory for the control treatment (4.01 and 1.39, respectively) and for the experimental treatment (4.35 and 1.41, respectively).

Considering the FA profile of tilapia fillets, it can be said that conjugated FA derived from alpha-linolenic fatty acid were incorporated into the fillets, and the CLnA after 10 days of treatment, the CLnA percentage was $1.02 \%$, confirming the buiding up of these isomers in the muscle tissue of the fish. Kim et al., (2002) and Yang et al., (2005) showed that the supplementation of $\alpha$-ESA acid in mice and rats resulted in its conversion into the isomer of linoleic acid cis9, trans11-18:2. Tsuzuki et al., (2004) also reported that a-ESA acid is partially saturated at position 13 and converted into 9c11t-CLA.

\section{Conclusions}

The fish adapted to the tung oil-enriched treatment. Conjugated FA were incorporated into GIFT fillets, and CLA was biosynthesized from the consumed CLnA. In conclusion, tilapia fed tung oil-enriched diets can be included in the human diet to increase the intake of CLA and CLnA conjugated fatty acids, as well as the intake of other fatty acids with important nutritional value, such as LNA, EPA, and DHA.

\section{References}

BLIGH, F. G.; DYER, W. J. A rapid method of total lipid extraction and purification. Canadian Journal of Biochemistry and Physiology, v. 37, p. 911-917, 1959. PMid:13671378. http://dx.doi.org/10.1139/ o59-099

BELLIDO, C. et al. The Mediterranean and CHO diets decrease VCAM1 and E-selectin expression induce by low density lipoprotein in HUVECs. Nutrition, Metabolism, and Cardiovascular Diseases, v. 16, p. 524-530, 2006. PMid:17126767. http://dx.doi.org/10.1016/j. numecd.2005.09.007

$\mathrm{CAO}, \mathrm{Y}$. et al. Identification and characterization of conjugated linolenic acid isomers by Ag+-HPLC and NMR. Journal of Agricultural and Food Chemistry, v. 54, p. 9004-9009, 2006. PMid:17117784. http:// dx.doi.org/10.1021/jf0616199

CUNNIFF, P. A. Official methods of Analysis of AOAC international. 6th ed. Arlington: AOAC, 1998.

DESTAILLATS, F. et al. Metabolites of Conjugated Isomers of alphaLinolenic Acid (CLnA) in the Rat. Journal of Agricultural and Food Chemistry, v. 53, p. 1422-1427, 2005. PMid:15740017. http:// dx.doi.org/10.1021/jf0481958

FÜLBER, V. M. et al. Desempenho comparativo de três linhagens de tilápia do Nilo Oreochromis niloticus em diferentes densidades de estocagem. Acta Scientiarum, v. 31, p. 177-182, 2009.

JOSEPH, J. D.; ACKMAN, R. G. Capillary column gas-chromatographic method for analysis of encapsulated fish oils and fish oil ethylesters- collaborative study. Journal of AOAC International, v. 75, p. 488-506, 1992.

JUSTI, K. C. et al. The influence of feed supply time on the fatty acid profile of Nile tilapia (Oreochromis niloticus) fed on a diet enriched with n-3 fatty acids. Food Chemistry, v. 80, p. 489-493, 2003. http:// dx.doi.org/10.1016/S0308-8146(02)00317-5

KIM, N. D. et al. Chemopreventive and adjuvant therapeutic potential of pomegranate (Punica granatum) for human breast cancer. Breast Cancer Research and Treatment, v. 71, p. 203-217, 2002. PMid:12002340. http://dx.doi.org/10.1023/A:1014405730585

MARTIN, C. A. et al. Ácidos graxos poli-insaturados ômega-3 e ômega-6: importância e ocorrência em alimentos. Revista de Nutrição, v. 19, p. 761-770, 2006. http://dx.doi.org/10.1590/S141552732006000600011

NOVA, C. M. V. M.; GODOY, H. T.; ALDRIGUE, M. L. Composição química, teor de colesterol e caracterização dos lipídios totais de tilápia (Oreochromis niloticus) e pargo (Lutjanus purpureus). Ciência e Tecnologia de Alimentos, v. 25, p. 430-436, 2005. http:// dx.doi.org/10.1590/S0101-20612005000300007

OMENA, C. M. B. et al. Reflexos da utilização de farelo de coco sobre o valor nutricional do filé de tilápia-do-nilo (Oreochromis niloticus Linnaeus, 1857). Ciência e Tecnologia de Alimentos, v. 30, p. 674-679, 2010. http://dx.doi.org/10.1590/S010120612010000300017

SEÇKIN, K. A. et al. Conjugated linoleic acid (CLA) concentration, fatty acid composition and cholesterol content of some Turkish dairy products. Food Science and Technology International, v. 38, p. 909-915, 2005.

SIMAS, R. C. et al. Instantaneous characterization of vegetable oils via TAG and FFA profiles by easy ambient sonic-spray ionization mass spectrometry. Analyst, v. 135, p. 738-744, 2010. http://dx.doi. org/10.1039/b923272a

SIMOPOULOS, A. P. The importance of the ratio of omega-6/omega-3 essential fatty acids. Biomedicine \& Pharmacotherapy, v. 56, p. 365-379, 2002. http://dx.doi.org/10.1016/S0753-3322(02)00253-6

SOUZA, N. E. et al. Manipulation of fatty acid composition of Nile tilapia (Oreochromis niloticus) fillets with flaxseed oil. Journal of the Science of Food and Agriculture, v. 87, p. 1677-1681, 2007. http://dx.doi.org/10.1002/jsfa.2877

SUZUKI, R. et al. Cytotoxic effect of conjugated trienoic fatty acids on mouse tumor and human monocytic leukemia cells. Lipids, v. 36, p. 477-482, 2001. PMid:11432460. http://dx.doi.org/10.1007/ s11745-001-0746-0

TSUZUKI, T. et al. Alpha-Eleostearic acid (9Z11E13E-18:3) is quickly converted to conjugated linoleic acid (9Z11E-18:2) in rats. Journal Nutrition, v. 134, p. 2634-2639, 2004. PMid:15465759. 
VISENTAINER, J. V. et al. Influence of diets enriched with flaxseed oil on the alpha-linolenic, eicosapentaenoic and docosahexaenoic fatty acid in Nile tilapia (Oreochromis niloticus). Food Chemistry, v. 90, p. 557-560, 2005. http://dx.doi.org/10.1016/j.foodchem.2004.05.016

WASHINGTON. National Research Council - NRC. Nutrient requirements of fish. Washington: National Washington Academy Press, 1993. 114 p.

YANG, L. et al. Oxidative stability of conjugated linolenic acids. Journal of Agricultural and Food Chemistry, v. 57, p. 4212-4217, 2009. PMid:19368396. http://dx.doi.org/10.1021/jf900657f
YANG, L. et al. R-Linolenic acid but not conjugated linolenic acid is hypocholesterolaemic in hamsters. British Journal of Nutrition, v. 93, p. 433-438, 2005. PMid:15946404. http://dx.doi.org/10.1079/ BJN20041365

YASUI, Y. M. et al. Bitter gourd seed fatty acid rich in $9 c, 11 t, 13 t-$ conjugated linolenic acid induces apoptosis and up-regulates the GADD45, p53 and PPARgamma in human colon cancer Caco-2 cells. Prostaglandins, Leukotrienes \& Essential Fatty Acids, v. 73, p. 113-119, 2005. PMid:15961301. http://dx.doi.org/10.1016/j. plefa.2005.04.013 